DOI: https://doi.org/10.24127/ajpm.v9i4.3161

\title{
ANALISIS KEMAMPUAN BERPIKIR KREATIF DALAM MEMECAHKAN MASALAH BERDASARKAN KEPRIBADIAN DAN STATUS PEKERJAAN
}

\author{
Marlinda Indah Eka Budiarti ${ }^{1 *}$, Laila Qadriyani Malikin ${ }^{2}$ \\ ${ }^{1 * 2}$ Universitas Muhammadiyah Sorong, Papua, Indonesia \\ ${ }^{*}$ Corresponding author. \\ E-mail: $\quad$ indah.eka43@gmail.com ${ }^{1 *}$ \\ qadriyanilaila@gmail.com $^{2)}$
}

Received 14 October 2020; Received in revised form 12 December 2020; Accepted 31 December 2020

\begin{abstract}
Abstrak
Adapun tujuan pada penelitian ini adalah untuk mengetahui bagaimana kemampuan berpikir kreatif mahasiswa dalam menyelesaikan soal matematika berdasarkan kepribadian dan pekerjaan. Jenis penelitian yang digunakan adalah deskriptif. Pendekatan yang digunakan adalah kualitatif. Subjek penelitian ini dilakukan pada delapan Mahasiswa. Data yang diperoleh dalam penelitian ini berupa:1) data hasil tes kepribadian MBTI yang berupa alat tes, yang akan diberikan kepada Mahasiswa; 2) data hasil tes pemecahan masalah yang berupa uraian yang diberikan kepada Mahasiswa; 3) dari hasil wawancara terhadap Mahasiswa. Instrument pendukung yang digunakan dalam penelitian ini diantaranya yaitu:1) alat tes Myers-Briggs Type Indicator (MBTI); 2) soal tes pemecahan masalah; 3) pedoman wawancara; 4) alat perekam. Teknik pengumpulan data yang digunakan dalam penelitian ini adalah triangulasi sumber, diantaranya adalah: 1) tes Myers-Briggs Type Indicator (MBTI); 2) tes pemecahan masalah; 3) wawancara. Hasil dari penelitian ini adalah Berpikir kreatif ekstrovert mempunyai pekerjaan dalam pemecahan masalah, sudah mampu memenuhi kreteria fluency, flexibility dan originality. Sedangkan, estrovert yang tidak memiliki pekerjaan belum mampu memenuhi kreteria flexibility dan originality. Selanjutnya berpikir kreatif introvert yang memiliki pekerjaan dalam pemecahan masalah, sudah memenuhi kreatifitas fluency, flexibility, dan originality. Sedangkan berpikir kreatif introvert tidak memiliki pekerjaan dalam pemecahan masalah, sudah mampu memenuhi kreatifitas fluency. Namun, belum dapat memenuhi kriterian pada tahap flexibility dan originality.
\end{abstract}

Kata kunci: kemampuan berpikir kreatif; kepribadian; pekerjaan

\begin{abstract}
The purpose of this study was to determine how students' creative thinking skills in solving math problems based on personality and work. This type of research is descriptive. The approach used is qualitative. The subject of this research was conducted on eight students. The data obtained in this study are: 1) data on the MBTI personality test results in the form of a test kit, which will be given to students; 2) data on problem solving test results in the form of descriptions given to students; 3) from the results of interviews with students. The supporting instruments used in this study include: 1) the Myers-Briggs Type Indicator (MBTI) test kit; 2) problem solving test questions; 3) interview guidelines; 4) recording device. The data collection technique used in this study was source triangulation, including: 1) the Myers-Briggs Type Indicator (MBTI) test; 2) problem-solving tests; 3) interview. The results of this study are that extrovert creative thinking has a job in problem solving, is able to meet the criteria of fluency, flexibility and originality. Meanwhile, estroverts who do not have a job have not been able to meet the flexibility and originality criteria. Furthermore, introvert creative thinking who has a job in problem solving, has fulfilled the creativity of fluency, flexibility, and originality. Meanwhile, introvert creative thinking does not have a job in problem solving, it is able to fulfill the creativity fluency. However, he has not been able to meet the criteria on the flexibility and originality stages.
\end{abstract}

Keywords: creative thinking skills; personality; profession 
DOI: https://doi.org/10.24127/ajpm.v9i4.3161

\section{PENDAHULUAN}

Pada era globalisasi saat ini sangat dibutuhkannya ide - ide kreatif dari anak bangsa, yang mana ide-ide kreatif itu akan muncul bila sering dibiasakan atau dilakukan sehingga seseorang mampu membudayakan berfikir kreatif. Salah satu tujuan pembelajaran matematika adalah membiasakan mahasiswa untuk berpikir kreatif. Kemampuan berpikir kreatif bukan merupakan suatu kemampuan yang dapat dikembangkan dengan sendirinya seiring dengan perkembangan fisik manusia. Kemampuan ini harus dilatih melalui pemberian stimulus yang menuntut seseorang untuk berpikir kreatif. Universitas sebagai satu institusi penyelenggaraan pendidikan memiliki tanggung jawab untuk membantu peserta didiknya mengembangkan kemampuan berpikir kreatif.

Berdasarkan hasil observasi selama pembelajaran matematika, banyak dari mahasiswa kurang dapat mengerjakan, pada saat di berikan soalsoal berkaitan dengan pemecahan masalah. Hal ini menjelaskan bahwa kurang terlatihnya mahasiswa pada soal-soal pemecahan masalah yang memerlukan lebih banyak dalam mengkoneksikan pengetahuan, kaitannya dengan matematika pada umumnya. Agar dapat menjawab soal dengan berbagai jawaban yang diinginkan. Berdasarkan hasil wawancara menyebutkan bahwa, sebagian dari mahasiswa memiliki pekerjaan yang mana sebagian lagi pure sebagai mahasiswa. Mahasiwa yang bekerja banyak yang tidak ada kaitannya dengan pendidikan. Hal ini berkaitan dengan kebiasaan mahasiswa melatih pengetahuan dalam memecahkan soal. Serta kepribadian mahasiswa yang berkaitan dengan bagaimana menyampaikan maksud dan tujuan dari hasil pemecahan masalah. Sehingga penulis ingin mengeksplor kemampuan berpikir kritis mahasiswa di Universitas Muhammadiyah Sorong.

Faktanya, hasil penelitian menunjukkan rendahnya kemampuan berpikir kreatif pada peserta didik (Purba, et. al. 2017). Hal ini sejalan dengan TIMSS terungkap bahwa peserta didik di Indonesia lemah dalam menyelesaikan soal-soal permasalahan matematika yang berkaitan dengan jastifikasi atau pembuktian, pemecahan masalah yang memerlukan penalaran , menentukan generalisasi atau konjektur dan menentukan hubungan antara datadata atau fakta yang diberikan. baik faktor internal dan eksternal. Faktor internal terdiri dari intelijen, motivasi, minat, bakat dan kemampuan matematika (Rasiman, 2015). Banyak variabel yang mempengaruhi dalam menyelesaikan suatu masalah diantaranya adalah psikologis (Marcia, 2010). Adapun beberapa penelitian yang menunjukkan bahwa adanya perbedaan kemampuan intelek seseorang dalam berpikir berdasarkan kepribadian seseorang (Budiarti \& Ruslan, 2018; Budiarti, Ruslan, \& Kahar, 2018).

Adapun penelitian yang terkait dengan berpikir kreatif (Hasanah, Mardiyana, \& Sutrima, 2013). menunjukkan adanya perbedaan proses berpikir dalam pemecahan masalah berdasarkan gender dan tipe kepribadian introvert dan ekstrovert. Rasiman (2015) menunjukkan peserta didik dengan tipe kepribadian thinking memiliki kemampuan berpikir karena peserta didik memenuhi semua tahapan saat memecahkan masalah. Adapun perbedaan penelitian ini adalah berkaitan dengan status pekerjaannya yang dibedakan menjadi dua yaitu mahasiswa yang bekerja dan tak bekerja. Kemampuan ini berkaitan 
dengan pengalaman seseorang dalam melakukan sesuatu. Sehingga seorang terbiasa mengeluarkan kemampuannya. Kemampuan seseorang dipengaruhi beberapa faktor yaitu internal dan eksternal, salah satunya adalah berkaitan dengan lingkungan. Berdasarkan hal ini, maka penulis ingin meneliti berdasarkan status pekerjaan, karena mengingat mahasiswa ada yang sudah bekerja. Sehingga penelitian ini untuk mengeksplor kemampuan berpikir kreatif dan menyelesaikan soal matematika berdasarkan kepribadian dan srtatus pekerjaan.

\section{METODE PENELITIAN}

Jenis penelitian yang digunakan adalah deskriptif. Pendekatan yang digunakan adalah kualitatif. Subjek penelitian ini dilakukan pada delapan Mahasiswa yang memiliki kriteria seperti, dua mahasiswa yang berkerja mempunyai kepribadian introvert dan dua mahasiswa tidak bekerja yang berkepribadian ekstrovert, dua mahasiswa yang tidak bekerja dengan kepribadian ekstrovert dan dua mahasiswa yang bekerja dengan kepribadian ekstrovert, dengan menggunakan angket tipe kepribadian dengan menggunakan alat tes MBTI. Cara pengambilan subjek pelitian yaitu dengan delapan mahasiswa yang telah dipilih dengan kriteria, dites dengan soal untuk mengetahui bagaimana proses pemecahan masalah pada setiap peserta didik, kemudian dilanjutkan dengan wawancara untuk mengetahui bagaimana kemampuan berpikir kreatif setiap mahasiswa.

Data yang diperoleh dalam penelitian ini berupa:1) data hasil tes kepribadian MBTI yang berupa alat tes, yang akan diberikan kepada Mahasiswa; 2) data hasil tes pemecahan masalah yang berupa uraian yang diberikan kepada Mahasiswa; 3) dari hasil wawancara terhadap Mahasiswa. Instrument pendukung yang digunakan dalam penelitian ini diantaranya yaitu:1) alat tes Myers-Briggs Type Indicator (MBTI); 2) soal tes pemecahan masalah; 3) pedoman wawancara; 4) alat perekam. Teknik pengumpulan data yang digunakan dalam penelitian ini adalah triangulasi sumber, diantaranya adalah: 1) tes Myers-Briggs Type Indicator (MBTI); 2) tes pemecahan masalah; 3) wawancara.

Teknik analisis data yang digunakan pada penelitian ini adalah data kualitatif. Data tes pemecahan masalah adalah menggunakan tahapan reduksi data yang meliputi:1) memproses hasil tes kepribadian dan satatus pekerjaan mahasiswa; 2) mengoreksi hasil tes pemecahan masalah subjek penelitian; 3) setelah hasil tes pemecahan masalah diperoleh, dilakukan wawancara. Penyajian datanya dilakukan dalam bentuk naratif. Adapun pedoman penilaian kemampuan berpikir kreatif siswa dalam menyelesaikan masalah matematika dapat dilihat pada Tabel 1.

Tabel 1. Pedoman penilaian kemampuan berpikir kreatif siswa dalam menyelesaikan masalah matematika.

\begin{tabular}{cccccc}
\hline No. & $\begin{array}{c}\text { Indikator } \\
\text { berpikir kreatif } \\
\text { peserta didik }\end{array}$ & $\begin{array}{c}\text { Indikator } \\
\text { pemecahan } \\
\text { masalah }\end{array}$ & Indikator penilaian & Skor \\
\hline $\mathbf{1}$ & $\begin{array}{c}\text { Fluency Mampu } \\
\text { menghasilkan } \\
\text { banyak jawaban }\end{array}$ & $\begin{array}{c}\text { Proses } \\
\text { penyelesaian } \\
\text { masalah }\end{array}$ & \begin{tabular}{c} 
Apabila siswa tidak menjawab \\
\cline { 3 - 6 }
\end{tabular} & $\begin{array}{l}\text { Apabila siswa memberikan satu penyelesaian } \\
\text { masalah dengan jawaban benar }\end{array}$ & 1 \\
& & & & &
\end{tabular}


DOI: https://doi.org/10.24127/ajpm.v9i4.3161

\begin{tabular}{|c|c|c|c|c|}
\hline No. & $\begin{array}{c}\text { Indikator } \\
\text { berpikir kreatif } \\
\text { peserta didik } \\
\end{array}$ & $\begin{array}{c}\text { Indikator } \\
\text { pemecahan } \\
\text { masalah }\end{array}$ & Indikator penilaian & Skor \\
\hline & & matematika & $\begin{array}{l}\text { Apabila siswa memberikan lebih dari satu } \\
\text { penyelesaian masalah dengan jwaban kurang tepat }\end{array}$ & 2 \\
\hline & & & $\begin{array}{l}\text { Apabila siswa memberikan lebih dari satu } \\
\text { penyelesaian masalah dengan jawaban bener dan } \\
\text { tepat }\end{array}$ & 3 \\
\hline \multirow[t]{4}{*}{2} & \multirow{4}{*}{$\begin{array}{l}\text { Flexibility } \\
\text { Mampu } \\
\text { menghasilkan } \\
\text { jawaban yang } \\
\text { bergam dan } \\
\text { dapat } \\
\text { menggunakan } \\
\text { berbagai cara } \\
\text { pendekatan } \\
\text { dalam menjawab }\end{array}$} & \multirow{4}{*}{$\begin{array}{c}\text { Membuat } \\
\text { rencana } \\
\text { penyelesaian } \\
\text { masalah, Proses } \\
\text { penyelesaian } \\
\text { masalah } \\
\text { matematika }\end{array}$} & Apabila tidak bisa menjawab & 0 \\
\hline & & & $\begin{array}{l}\text { Apabila siswa dapat menyelesaiakn rencana (sketsa) } \\
\text { dengan menggunakan berbagai cara pendekatan } \\
\text { dalam menjawab soal tetapi jawaban belum tepat }\end{array}$ & 1 \\
\hline & & & $\begin{array}{l}\text { Apabila siswa dapat menyelesaiakn rencana (sketsa) } \\
\text { dengan menggunakan berbagai cara pendekatan } \\
\text { dalam menjawab tetapi soal jawaban kurang tepat }\end{array}$ & 2 \\
\hline & & & $\begin{array}{l}\text { Apabila siswa dapat menyelesaiakn rencana (sketsa) } \\
\text { dengan menggunakan berbagai cara pendekatan } \\
\text { dalam menjawab soal benar dan tepat }\end{array}$ & 3 \\
\hline \multirow[t]{4}{*}{3} & \multirow{4}{*}{$\begin{array}{l}\text { Originality } \\
\text { Mampu } \\
\text { memberikan } \\
\text { penyelesaian } \\
\text { masalah yang } \\
\text { berbeda }\end{array}$} & \multirow{4}{*}{$\begin{array}{c}\text { Proses } \\
\text { penyelesaian } \\
\text { masalah } \\
\text { matematika }\end{array}$} & Apabila siswa tidak menjawab & 0 \\
\hline & & & $\begin{array}{l}\text { Apabila siswa membuat penyelesaian masalah sama } \\
\text { dengan kelompok lain atau teman lain jawaban } \\
\text { bener }\end{array}$ & 1 \\
\hline & & & $\begin{array}{l}\text { Apabila siswa membuat penyelesaian masalah } \\
\text { berbeda dengan kelompok lain atau teman lain } \\
\text { jawaban kurang tepat }\end{array}$ & 2 \\
\hline & & & $\begin{array}{l}\text { Apabila siswa membuat penyelesaian masalah } \\
\text { berbeda dengan kelompok lain atau teman lain } \\
\text { jawaban bener dan tepat }\end{array}$ & 3 \\
\hline
\end{tabular}

\section{HASIL DAN PEMBAHASAN}

Berpikir Kreatif Peserta Didik

Ekstrovert serta Memiliki Pekerjaan

dalam Menyelesaikan Soal

Berdasarkan hasil tes MBPTI

dan hasil soal pemecahan masalah matematika yang telah dikumpulkan mahasiswa dengan kepribadian ekstrovert yang memiliki pekerjaan maka subjek yang terpilih, yaitu $\mathrm{AAB}$ dan AAI.

1. Subjek AAB menyelesaikan dua soal, akan tetapi dari dua soal tersebut hanya satu soal yang memiliki hasil jawaban benar. Hasil bepikir kreatif siswa dalam pemecahan masalah subjek AAB pada soal nomor satu pada
Gambar 1 dan nomor dua pada Gambar 2.

\begin{tabular}{c}
$\int 2 x \cdot \frac{\cos \left(x^{2}-5\right)}{\operatorname{cotan}\left(x^{2}-5\right)} \frac{\sin \left(x^{2}-5\right)}{\sin \left(x^{2}-5\right) d x}$ \\
\hline$u=x^{2}-5$ \\
$d u=2 x d x$ \\
$d x=\frac{1}{2 x} d u$ \\
\hline $\int 2 x \cdot \sin \left(x^{2}-5\right) d x$ \\
$\int 2 x \cdot \sin u \cdot \frac{1}{2 x} d u$ \\
$=-\cos u+c$ \\
$=-\cos x^{2}-5+c$
\end{tabular}

Gambar 1. Tes tulis berpikir kreatif oleh subjek AAB pada nomor 1 . 
DOI: https://doi.org/10.24127/ajpm.v9i4.3161
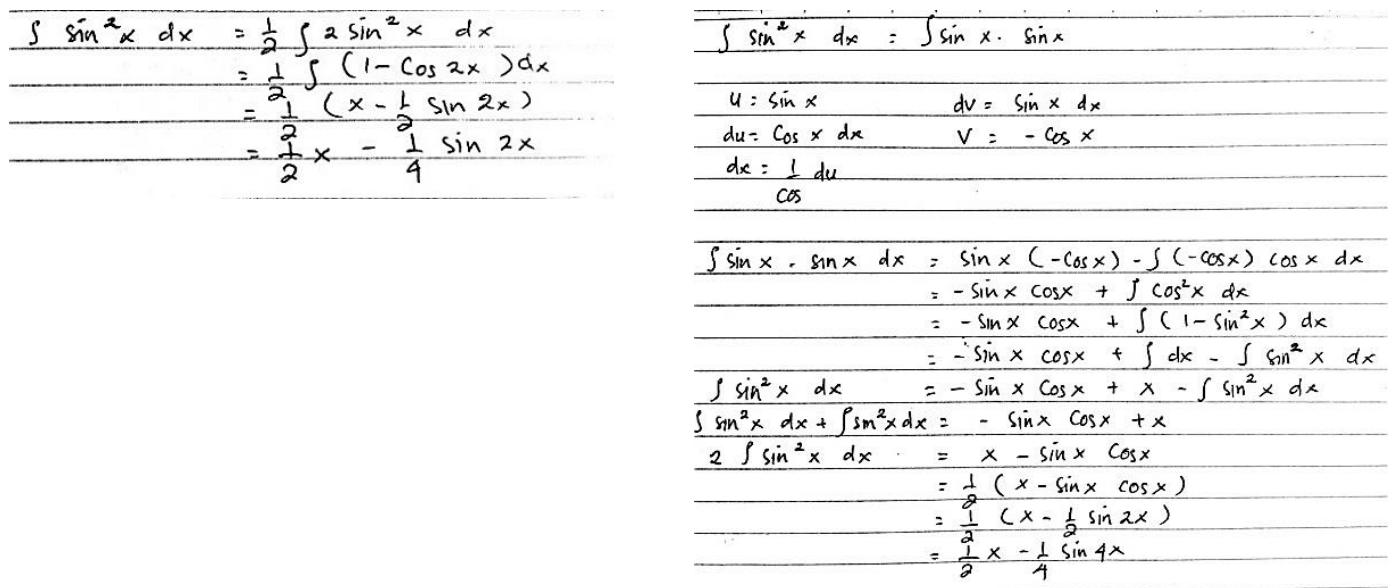

Gambar 2. Tes tulis berpikir kreatif oleh subjek AAB pada nomor 2 .

Berdasarkan hasil tes tulis berpikir kreatif, subjek ABB pada permasalahan tahapan fluency, kreatifitas dikarenakan subjek $\mathrm{AAB}$ mampu memberikan satu penyelesaian masalah dengan jawaban benar. Tapi pada soal nomor 1 subjek AAB, kurang kreatif hal ini dikarenakan subjek AAB belum mampu memberikan lebih dari satu penyelesaian masalah dengan jawaban benar dalam bentuk tulisan dan hanya menjelaskan pada saat wawancara. Namun, pada tahapan flexibility subjek AAB kreatif dikarenakan subjek AAB dapat memberikan menyelesaikan soal dengan beragam jawaban. Selanjutnya pada tahapan originality, subjek $\mathrm{AAB}$ sudah kreatif dikarenakan subjek AAB dapat memberikan menyelesaikan soal

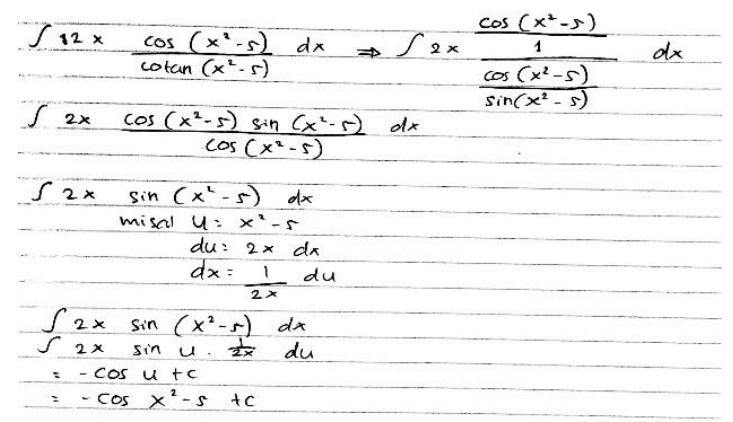

Gambar 3. Tes tulis berpikir kreatif oleh subjek AAI pada nomor 1 dengna beragam dan tidak diketahui oleh teman yang lain. Hal ini diperkuat dari hail wawancara subjek AAB bahwa saat subjek mengerjakan soal nomor 1, sempat ragu untuk mengganti cotan dengan 1/ tan. Sehinnga dapat disimpulkan bahwa subjek AAB sudah mampu memenuhi kreteria fluency dan originality.Namun, subjek AAB belum mampu memenuhi kreteria flexibility

2. Subjek AAI dapat. Akan tetapi, dari penyelesaian tersebut, ia belum mampu menyelesaiakan penyelesaian dengan jawaban yang benar. Hasil bepikir kreatif siswa dalam pemecahan masalah subjek AAI pada soal nomor 1 pada Gambar 3 dan nomor 2 pada Gambar 4.

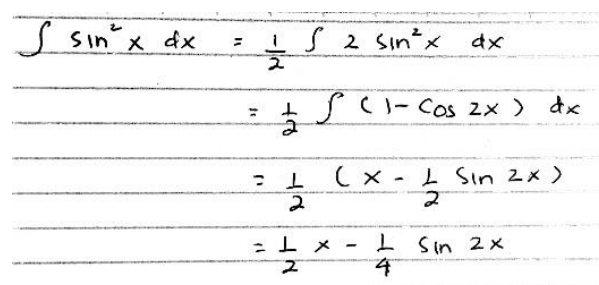

Gambar 4 Tes tulis berpikir kreatif oleh subjek AAI pada nomor 2 
DOI: https://doi.org/10.24127/ajpm.v9i4.3161

Berdasarkan hasil tes tulis berpikir kreatif, subjek AAI pada permasalahan tahapan fluency, subjek AAI kreatif. Hal ini dapat dilihat dari ketika subjek dapat memberikan satu penyelesaian soal dengan benar. Namun, pada tahapan flexibility, subjek AAI kurang kreatif dikarenakan belum mampu menghasilkan jawaban yang beragam dalam bentuk tulisan, hanya dapat menjelaskan dalam bentuk wawancara. Selanjutnya pada tahapan originality, subjek AAI tidak kreatif dikarenakan belum mampu memberikan penyelesaian masalah yang berbeda dengan teman lainnya dengan jawaban benar. Hal ini diperkuat dari hasil wawancara subjek AAI yang menyatakan bahwa pada nomor 1, subjek meragukan jawaban cos/cotan dapat diubah menjadi $\cos / 1 /$ tan . Sehingga dapat disimpulkan bahwa subjek AAI kurang kreatif, dikarenakan subjek AAI hanya mampu memenuhi fluency. Sedangkan pada tahap flexibility, originality subjek belum dapat memenuhi indikatornya.

Adapun hasil subjek AAB dan AAI disajikan dalam bentuk grafik pada Gambar 5.

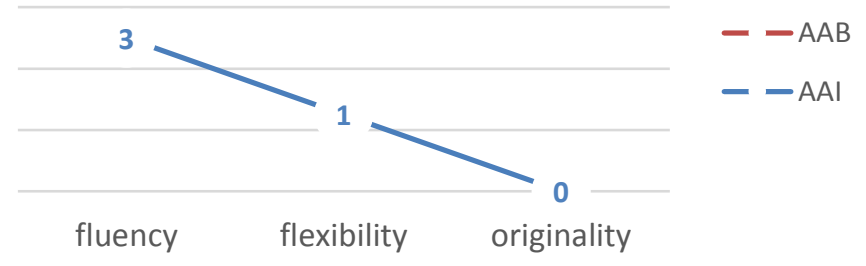

Gambar 5. Hasil berpikir kreatif peserta didik ekstrovert serta memiliki pekerjaan.

Berhasarkan hasil berpikir kritis peserta didik ekstrovert yang memiliki pekerjaan dapat disimpulkan bahwa kurang kreatif, dikarenakan hanya mampu memenuhi fluency. Hal ini terlihat dari bagaimana dapat menyelesaikan soal dan memberikan gagasan atas apa yang subjek kerjakan. Sedangkan pada tahap flexibility, originality subjek belum dapat memenuhi indikatornya. Hal ini terlihat pada saat subjek kurangnya pengetahuan subjek pada materi sehingga ia belum dapat memberikan jawaban yang beragam atas persoalan yang diberikan serta pada saat memberikan jawaban kurang dapat memberikan jawaban berbeda dari yang lainnya. Hal ini dikarenakan kurangnya pengetahuan tertentu. Hal ini berkaitan erat dengan perbedaan pekerjaan yang dimiliki kedua subjek. Sehingga menimbulkan perbedaan kemampuan. Hal ini diperjelas dengan wawancara dari $\mathrm{AAB}$ yang menyatakan bahwa pekerjaannya yaitu dibidang pengajaran sehingga $\mathrm{AAB}$ sering belajar mandiri dalam menyelesaikan berbagai macam persoalan. Hal ini sejalan dengan hasil penelitian (Ismayani, 2016; (Ikromi, 2018) yang menyatakan bahwa pengembangan berpikir kritis dapat meningkat dengan cara open-ended problem. Serta Abdurrozak \& Jayadinata (2016) menyatakan bahwa dengan menggunakan problem based learning terhadap kemampuan berpikir kreatif siswa. 
DOI: https://doi.org/10.24127/ajpm.v9i4.3161

\section{Berpikir Kreatif Peserta Didik} Ekstrovert Tidak Memiliki Pekerjaan Dalam Menyelesaikan Soal

Berdasarkan hasil tes MBPTI dan hasil soal pemecahan masalah matematika yang telah dikumpulkan mahasiswa dengan kepribadian ekstrovert yang tidak memiliki pekerjaan maka subjek yang terpilih, yaitu VEA dan NES.

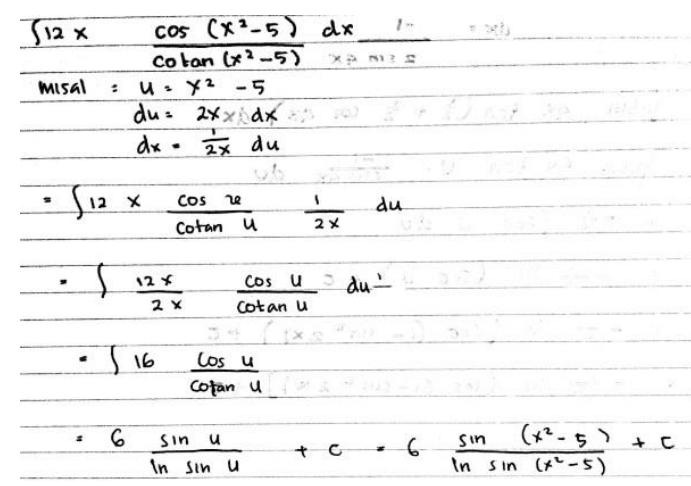

Gambar 6. Tes tulis berpikir kreatif oleh subjek VEA pada nomor 1

Berdasarkan hasil tes tulis berpikir kreatif, pada nomor 1 subjek VEA pada permasalahan tahapan fluency, kurang kreatif. Hal ini terlihat dari subjek yang belum dapat menyelesaikan persoalan dengan benar. Sedangkan pada nomor 2, subjek sudah kreatif, karna mampu menyelesaikan soal dengan benar. Namun, pada nomor1 tahapan flexibility dan oroginality, tidak kreatif dikarenakan subjek VEA belum mampu menghasilkan jawaban yang beragam dan belum dapat memberikan jawaban berbeda dari teman yang lain dengan benar. Hal ini dapat dilihat dari hasil tes tertulis yang dari pertama sudah salah soal dan dalam menyelesaikan soal yang salah. Ketika dilakukan wawancara subjek VEA ternyata pada saat mengerjakan soal, belum dapat membedakan integral dan turunan. Sehingga dapat disimpulkan bahwa
1. Subjek VEA menyelesaikan dua soal, akan tetapi dari kedua soal tersebut keduanya menghasilkan jawaban yang belum tepat. Subjek VEA belum mampu menyelesaiakan masalah dengan berbagai penyelesaian yang tepat. Hasil bepikir kreatif siswa dalam pemecahan masalah subjek VEA pada soal nomor satu pada Gambar 6 dan nomor dua pada Gambar 7.

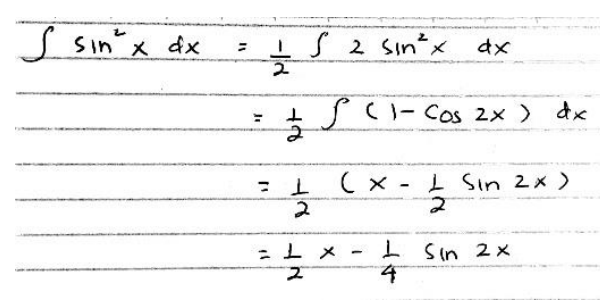

Gambar 7. Tes tulis berpikir kreatif oleh subjek VEA pada nomor 2

subjek VEA mampu memenuhi salah satu kreteria fluency, dan originality. Namun subjek VEA belum mampu memenuhi kreteria flexibility.

2. Subjek NES menyelesaikan dua soal dengan satu penyelesaian yang sama dengan jawaban yang benar. Hasil bepikir kreatif siswa dalam pemecahan masalah subjek NES pada soal nomor satu pada Gambar 8 dan nomor dua pada Gambar 9.

Berdasarkan hasil tes tulis berpikir kreatif, subjek NES pada permasalahan tahapan fluency, kurang kreatif. Hal ini dilihat dari pengerjaan nomor 1 hanya mampu memberikan satu penyelesaian masalah yang salah. Namun, pada tahapan flexibility dan originality, tidak kreatif dikarenakan subjek NES belum mampu menyelesaikan soal dengan beragam jawab dan berbeda dari teman lainnya. Hal ini dapat dilihat dari cara 
DOI: https://doi.org/10.24127/ajpm.v9i4.3161

penyelesaian soal yang salah. Hal ini sejalan dengan hasil wawancara subjek NES yang menyatakan bahwa subjek belum dapat membedakan antara turunan dan integral. Maka dapat disimpulkan bahwa subjek NES mampu memenuhi kreteria fluency. Sedangkan subjek NES belum mampu memenuhi kreteria flexibility dan originality.

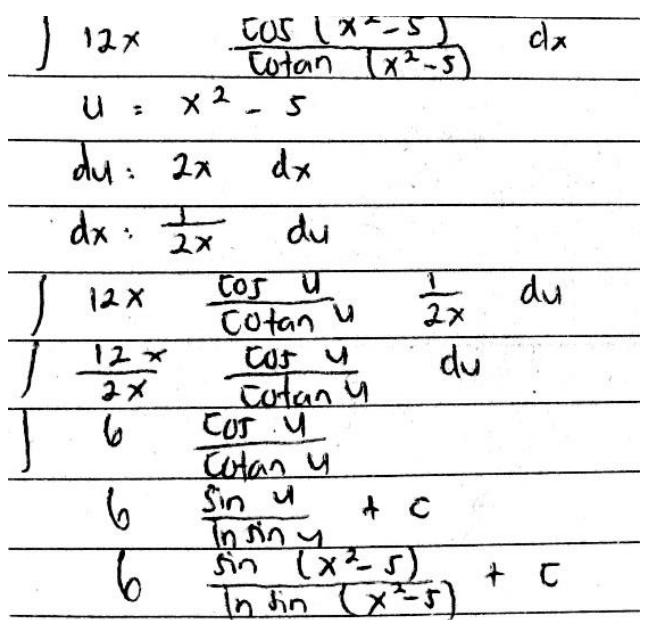

Gambar 8. Tes tulis berpikir kreatif oleh subjek NES pada nomor 1 .

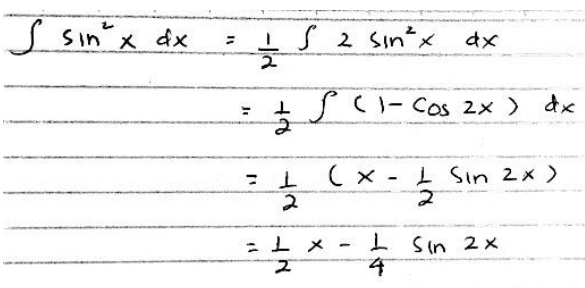

Gambar 9. Tes tulis berpikir kreatif oleh subjek NES pada nomor 2.

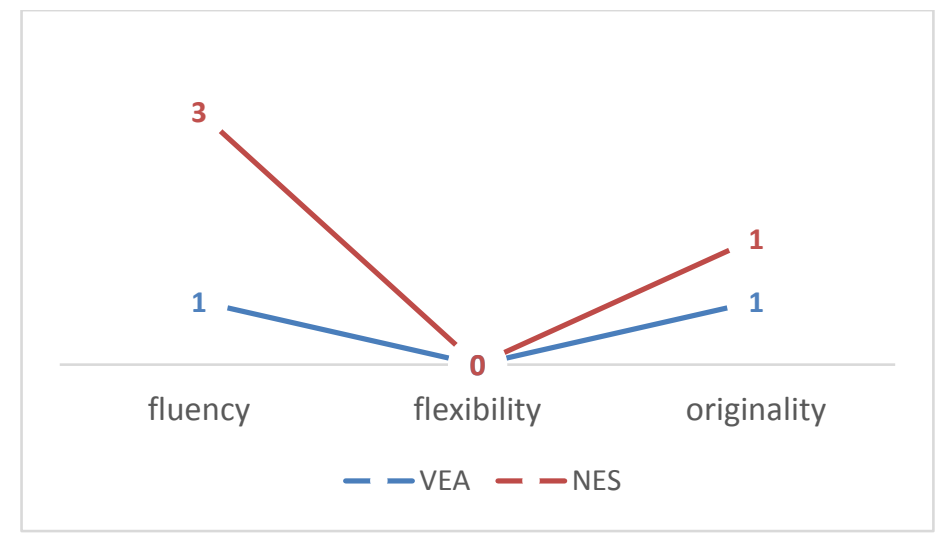

Gambar 10. Hasil berpikir kreatif peserta didik ekstrovert tidak memiliki pekerjaan dalam menyelesaikan soal.

Adapun hasil subjek VEA dan NES disajikan dalam bentuk grafik pada Gambar 10. Berdasarkan hasil berpikir kreatif peserta didik ekstrovert tidak memiliki pekerjaan dalam menyelesaikan soal, dapat disimpulkan bahwa subjek tidak kreatif. Hal ini terlihat dari cara subjek tidak dapat menyelesaikan soal. Sehingga dapat dipastikan bahwa subjek hanya sampai pada tahap fluency. Sedangkan pada tahap flexibility dan originality belum dapat memenuhi kriterianya. Berdasarkan hasil wawancara ketika ditanya berkaitan tidak adanya pekerjaan yang 
subjek lakukan dalam arti fokus menjadi mahasiswa, subjek mengatakan bahwa dari awal kurang minat dalam pembelajaran. Hal ini berkaitan erat dengan hasil penelitian (Nursa'adah \& Rosa, 2016; Tambunan, 2016)) yang menyatakan bahwa salah satu aspek yang mempengaruhi pengembangan berpikir kreatif ialah minat dalam belajar.

Berpikir Kreatif Peserta Didik Introvert Memiliki Pekerjaan Dalam Menyelesaikan Soal

Berdasarkan hasil tes MBPTI dan hasil soal pemecahan masalah

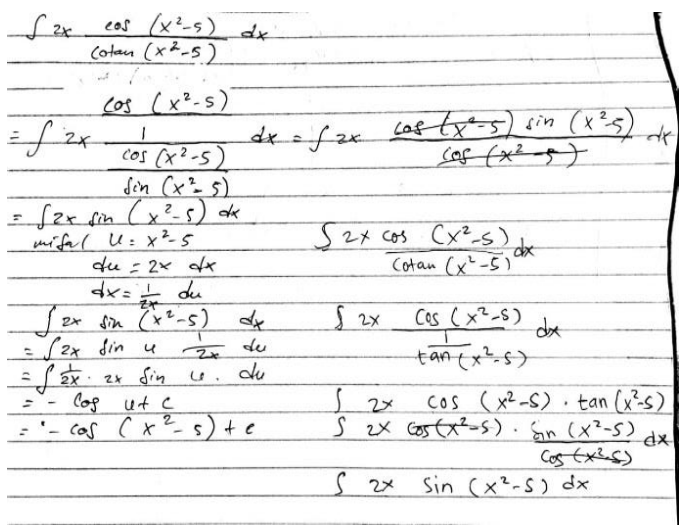

Gambar 11. Tes tulis berpikir kreatif oleh subjek EA pada nomor 1

Berdasarkan hasil tes tulis berpikir kreatif, subjek EA pada permasalahan fluency, sudah kreatif. Hal ini dapat dilihat dari hasil tes tulis yang menunjukkan bahwa subjek EA dapat menyelesaikan soal dengan benar. Selanjutnya, pada tahap flexibility, kreatif dikarenakan subjek EA sudah mampu menyelesaikan soal dengan beragam jawaban pada nomor 1. Sedangkan pada nomor 2 , subjek belum mapu memberikan jawaban beragam. Selanjutnya pada tahapan originality, kurang kreatif dikarenakan subjek EA pada nomor 2, belum matematika yang telah didapatlah mahasiswa dengan kepribadian introvert yang memiliki pekerjaan maka subjek yang terpilih, yaitu EA dan EP.

1. Subjek EA mampu menyelesaiakan dua soal dengan jawaban yang benar. Hasil bepikir kreatif siswa dalam pemecahan masalah subjek EA pada soal nomor 1 pada Gambar 11 dan pada soal nomor 2 pada Gambar12.

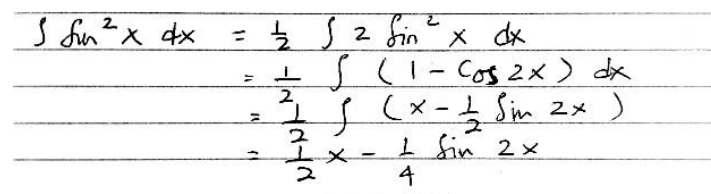

Gambar 12. Tes tulis berpikir kreatif oleh subjek EA pada nomor 2

mampu memberikan penyelesaian soal yang berbeda dari teman yang lain. Sehingga dapat diberikan kesimpulan bahwa, subjek EA cukup kreatif karena sudah dapat masuk pada tahap fluency dan originality walaupun belum mampu melalui tahapan flexibility. Hal ini diperkuat dari hasil wawancara subjek EA yang menyatakan bahwa subjek paham akan materi karena sering menggunakan untuk mengajarkan ke orang lain. Sehingga bahwa pembelajaran yang selalu digunakan akan menjadi sebuah keahlian. 
DOI: https://doi.org/10.24127/ajpm.v9i4.3161

2. Subjek EP mampu menyelesaiakan dua soal dengan jawaban yang benar. Hasil bepikir kreatif siswa dalam pemecahan masalah subjek EP pada soal nomor satu pada Gambar 13 dan pada soal nomor dua pada Gambar 14.

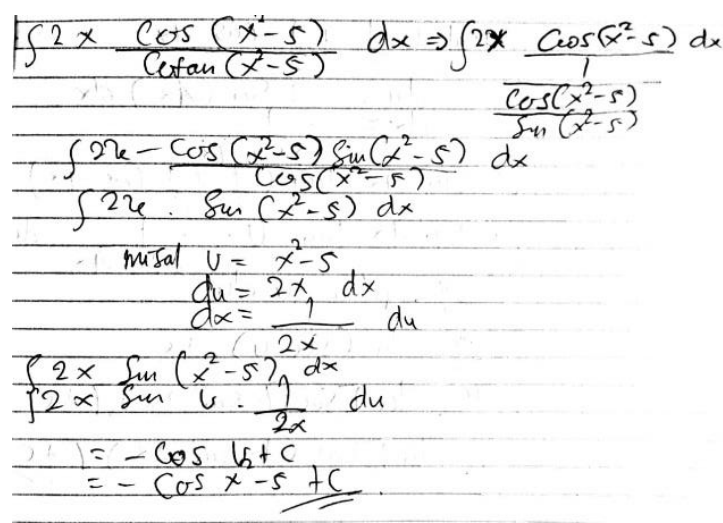

Gambar 13. Tes tulis berpikir kreatif oleh subjek EP pada nomor 1.

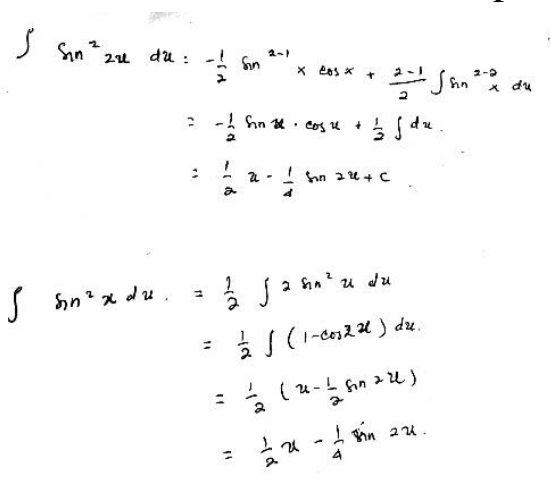

$$
\begin{aligned}
\int \sin ^{2} u d u & =\int \sin u \cdot \sin u . \\
u=\sin u & \quad d u=\sin u d u \\
d u & =\cos u d u \quad \cos d u . \quad \quad=-\cos u . \\
d u & =\frac{1}{\cos d x}=\sin u(-\cos u)-\int(-\cos u)(\cos u d u) \\
& =-\sin u \cos u+\int \cos ^{2} u d u \\
& =-\sin u \cos u+\int\left(1-\sin ^{2} u\right) d u . \\
& =-\sin u \cos u+\int d u-\int \sin ^{2} u d u \\
& =-\sin u \cos u+u-\int \sin ^{2} u d u . \\
\int \sin ^{2} u d u+\int \sin ^{2} u d u & =-\sin u \cos u+u . \\
2 \int \sin ^{2} u d u & =u-\sin u \cos u . \\
& =\frac{1}{2}(u-\sin u \cos u) \\
& =\frac{1}{2}\left(u-\frac{1}{2} \sin 2 u\right)=\frac{1}{2} u-\frac{1}{2} \sin 4 u .
\end{aligned}
$$

Gambar 14. Tes tulis berpikir kreatif olehsubjek EP pada nomor 2.

Berdasarkan hasil tes tulis berpikir kreatif, subjek EP pada permasalahan tahEPan fluency, kreatif dikarenakan subjek EP mampu memberikan lebih dari satu dalam menyelesaikan persoalan dengan tepat. Hal ini dapat terlihat dari jawaban yang diberikan benar dan pada saat wawancara yang mengopinikan tentang bentuk lain dari rumus trigonometri. Sedangkan, pada tahap flexibility, kreatif dapat ditunjukkan dengan subjek EP mampu menyelesaikaan soal dengan beragam jawaban yang tepat serta pada tahp originality yang mamapu memberikan jawaban yang berbeda dari lainnnya. Hal ini diperkuat dari hasil wawancara subjek EP yang mnyatakan bahwa subjek paham dengan betul materi yang selama ini diajarkan dan menggunakannya dalam mengajari teman. Kesimpulan yang dapat diambil bahwa subjek EP sudah memenuhi kreatifitas fluency,flexibility, dan originality.

Adapun hasil subjek EP dan EA disajikan dalam bentuk grafik pada Gambar 15. 
DOI: https://doi.org/10.24127/ajpm.v9i4.3161

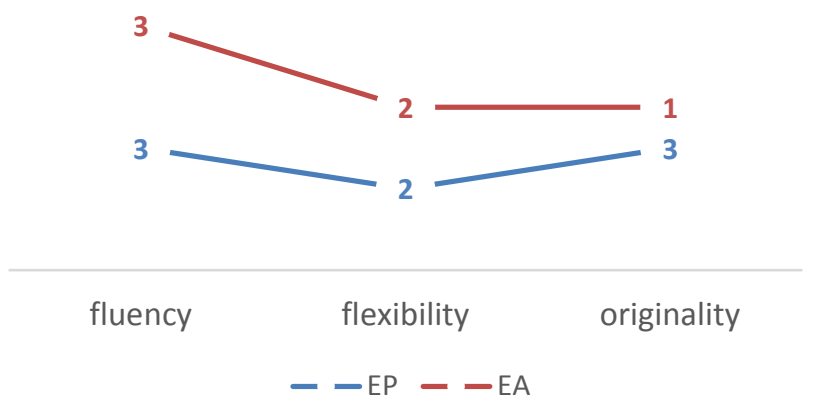

Gambar 15. Hasil berpikir kreatif peserta didik introvert memiliki pekerjaan dalam menyelesaikan soal.

Berdasarkan hasil berpikir kreatif peserta didik introvert memiliki pekerjaan dalam menyelesaikan soal dapat disimpulkan bahwa, subjek sudah kreatif hal ini dikarenakan jika dilihat dari hasil pengerjaan soal, subjek dapat menyelesaikan soal dengan benar, berarti sudah memenuhi tahap fluency. Selanjutnya sudah pada tahap flexibility dan originality. Hal ini terlihat dari cara penjelasan serta cara jawab soal yang runtut serta jelas dan berbeda dari teman lainnya. Hal ini dibuktikan dengan penjelasan subjek pada saat wawancara yang sangat memahamisoal dan materi yang diberikan. Jika ditinjau dari pekerjaannya, menunjukkan bahwa pekerjaan yang dimiliki subjek sangat membantu adanya pengembangan berpikir kreatif mahasiswa serta minat belajar mahasiswa yang mana menuntut mahasiswa sering melakukan drill dalam menyelesaikan berbagai soal. Hal ini sesuai dengan hasil penelitian Fadillah, A. (2016) perbedaan kemampuan berpikir kreatif matematis siswa yang diberi pembelajaran problem solving dengan siswa yang diberi pembelajaran konvensional. Hal ini menunjukkan bahwa efek drill yang dilakukan pada saat pembelajaran problem solving. Pada penelitian Tambunan (2016) yang menyatakan bahwa terdapat pengaruh interaksi yang signifikan strategi pembelajaran dan minat belajar siswa terhadap kemampuan berpikir kreatif matematis siswa pada mata pelajaran matematika. Sedangkan dilihat pada kepribadiannya, introvert lebih pada saat wawancara introvert lebih terstruktur dan terencana. Akan tetapi lebih individualis dalam mengerjakn sesuatu. Hal ini sejalan dengan penelitian (Pangestu \& Yunianta, 2019) pada subjek introvert lebih teliti dibandingkan ekstrovert, serta ada perbedaan berpikir mahasiswa berdasarkan kepribadiannya (Taher et al., 2018)

\section{Berpikir Kreatif Peserta Didik} Introvert tidak memiliki pekerjaan dalam menyelesaikan soal

Berdasarkan hasil tes MBPTI dan hasil soal pemecahan masalah matematika yang telah dikumpulkan mahasiswa dengan kepribadian introvert yang tidak memiliki pekerjaan maka subjek yang terpilih, yaitu ACA dan UCI.

1. Subjek ACA mampu menyelesaikan dua soal. Berdasarkan data yang didapatkan ACA dapat menyelesaikan kedua persoalan tersebut dengan benar 
bahkan pada nomor 2, ACA dapat memberikan lebih dari satu penyelesaian soal. Berikut adalah hasil bepikir kreatif siswa dalam pemecahan

$$
\begin{aligned}
& \text { - } 2 x \frac{\cos \left(x^{2}-5\right)}{\operatorname{cotan}\left(x^{2}-5\right)} d x \quad-\frac{\cos \left(x^{2}-5\right)}{\frac{\cos \left(x^{2}-5\right)}{\sin \left(x^{2}-5\right)}} d x \\
& \int 2 x \cdot \frac{\cos \left(x^{2}-5\right) \sin \left(x^{2}-5\right)}{\cos \left(x^{2}-5\right)} d x \\
& \int 2 x \cdot \sin \left(x^{2}-5\right) d x \\
& \text { misal } u=x^{2}-5 \\
& \begin{array}{l}
d u=2 x d x \\
d x=1
\end{array} \\
& \int 2 x \cdot \sin \left(x^{2}-5\right) d x \\
& \int 2 x-\sin u \cdot \frac{1}{2 x} d u \\
& =-\cos u+c \\
& \begin{array}{l}
-\cos u+c \\
-\cos x^{2}-5+c
\end{array}
\end{aligned}
$$

Gambar 16. Tes tulis berpikir kreatif oleh subjek ACA pada nomor 1.

Berdasarkan hasil tes tulis berpikir kreatif, pada tahapan fluency, kreatif dikarenakan subjek ACA mampu memberikan penyelesaian soal dengan benar. Selanjutnya, pada tahapan flexibility, dikatakan kreatif dikarenakan subjek ACA dapat memberikan jawaban lebih dari satu dengan benar. Selanjutnya pada tahapan originality, kreatif dikarenakan subjek ACA menyelesaikan permasalahan yang berbeda dari teman lain dengan benar. Hal ini diperkuat denga hasil wawancara bahwasanya ACA memahami materi ini dengan baik dan mencoba mengerjakannya berdasarkan materi yang telah diajarkan. Sehingga dapat disimpulkan bahwa ACA memenuhi kriteria fluency, flexibility, dan originality.

2. Subjek UCI mampu menyelesaiakan dua soal. Dari kedua penyelesaian tersebut ia sudah mampu menyelesaikan penyelesaian dengan jawaban yang benar, akan tetapi belum mampu memberikan alternatif penyelesaian soal yang lain. Hasil masalah subjek ACA pada soal nomor satu pada Gambar 16 dan pada soal nomor dua pada Gambar 17.

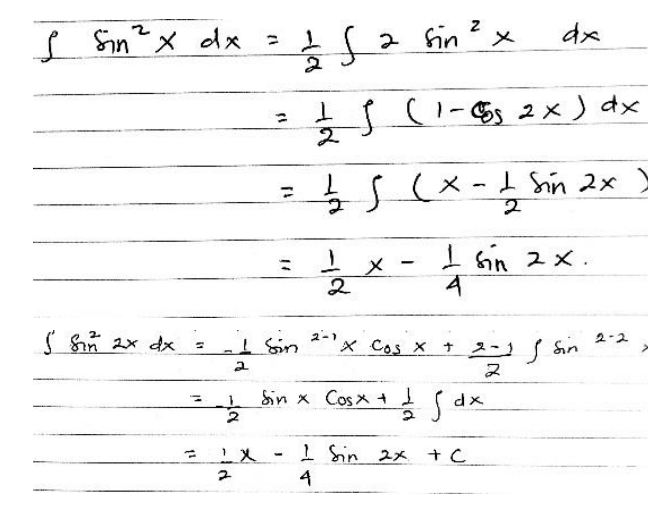

Gambar 17. Tes tulis berpikir kreatif oleh subjek ACA pada nomor 2 .

bepikir kreatif siswa dalam pemecahan masalah subjek UCI pada soal nomor satu pada Gambar 18 dan pada soal nomor dua pada Gambar 19.

Berdasarkan hasil tes tulis berpikir kreatif, subjek UCI pada permasalahan tahapan fluency, sudah kreatif, hal ini dapat dilihat dari hasil menyelesaikan soal UCI yang sdh benar. Sedangkan, pada tahapan flexibility, belum kreatif hal inidapat dilihat dari hasil penyelesaian soal yang belum beragam. Selanjutnya pada tahapan originality, kurang kreatif dikarenakan subjek UCI mampu menyelsaikan masalah yang sama dengan teman lain dengan jawaban benar. Hal ini sejalan dengan hasil wawancara UCI yang mengatakan bahwa telah dapat mengerjakan persoalan yang ada akan tetapi subjek belum dapat memberikan alternatif jawaban karena kurang pahamnya subjek bahwa dapat menyelesaiakan persoalan tersebut dengan rumus integral yang lain. Sehingga dapat disimpulkan bahwa, UCI hanya mampu memenuhi kreatifitas pada fluency. 
DOI: https://doi.org/10.24127/ajpm.v9i4.3161

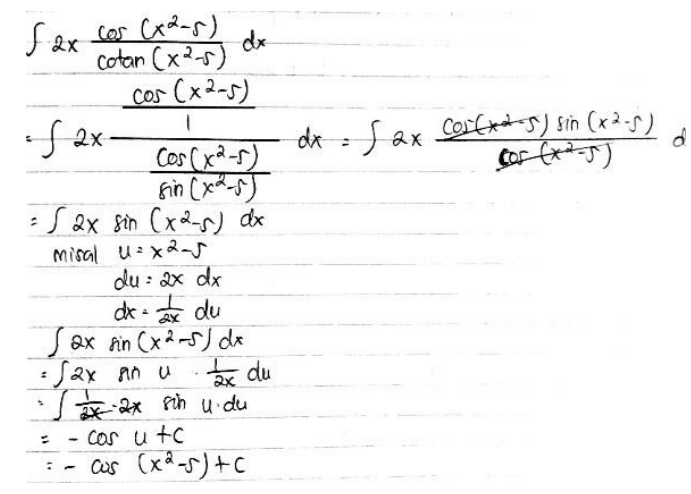

Gambar 18. Tes tulis berpikir kreatif oleh subjek UCI pada nomor 1.

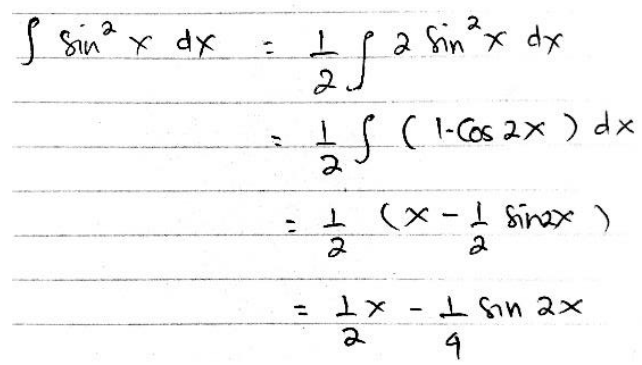

Gambar 19. Tes tulis berpikir kreatif oleh subjek UCI pada nomor 2.

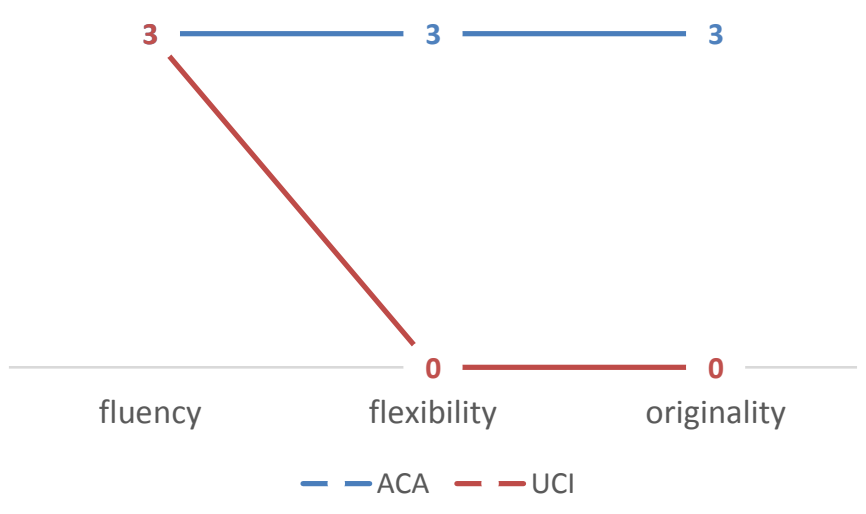

Gambar 20. Hasil berpikir kreatif peserta didik introvert tidak memiliki pekerjaan dalam menyelesaikan soal.

Adapun hasil subjek ACA dan UCI disajikan dalam bentuk grafik pada Gambar 20. Berdasarkan hasil berpikir kreatif peserta didik introvert tidak memiliki pekerjaan dalam menyelesaikan soal dapat disimpulkan kurang kreatif hal ini dikarenkan subjek sudah pada tahap fluency, dapat dilihat dari dapat menyelesaikan persoalan matematika dengan benar. Akan tetapi pada tahap flexibility dan originality hal ini dikarenkan subjek pada beberapa materi ada yang kurang paham. Ketika ditanya berkaitan dengan tidak adanya pekerjaan yang dimiliki subjek dan dikaitkan dengan lebih banyaknya waktu yang dapat digunakan untuk belajar subjek menanggapinya dengan kurangnya minat karena kelamaan tidak belajar bersama, yang dikarenkan covid serta kurangnya komunikasi mahasiswa saat belajar. Hal ini tidak sejalan dengan penelitian Nasution (2017) yang menyatakan bahwa kemandirian belajar siswa dapat meningkatkan berpikir kreatif siswa. Serta kaitannya juga dengan penelitian (Choridah, 2013) yang menyatakan bawa komunikasi merupakan salah satu cara yang dapat menstimulus berpikir kreatif karena dengan berkomunikasi yang baik, mahasiswa dapat mengemukakan ideidenya. 
DOI: https://doi.org/10.24127/ajpm.v9i4.3161

\section{KESIMPULAN DAN SARAN}

Berdasarkan hasil penelitian, dapat disimpulkan secara keseluruhan Berpikir kreatif ekstrovert mempunyai pekerjaan dalam pemecahan masalah, sudah mampu memenuhi kriteria fluency, flexibility dan originality. Sedangkan, estrovert yang tidak memiliki pekerjaan belum mampu memenuhi kreteria flexibility dan originality. Selanjutnya berpikir kreatif introvert yang memiliki pekerjaan dalam pemecahan masalah, sudah memenuhi kreatifitas fluency, flexibility, dan originality. Sedangkan berpikir kreatif introvert tidak memiliki pekerjaan dalam pemecahan masalah, sudah mampu memenuhi kreatifitas fluency. Namun, belum dapat memenuhi kriteria pada tahap flexibility dan originality.

Adapun saran yang dapat dilakukan untuk penelitian selanjutnya yaitu guru dapat memberikan motivasi belajar sehingga mahasiswa semangat dalam pembelajaran matematika, serta membiasakan mahasiswa dalam menyelesaikan berbagai latihan soal matematika lainnya, sehingga meningkatkan kemampuan berpikir kreatif mahasiswa pada cabang matematika lainnya.

\section{DAFTAR PUSTAKA}

Abdurrozak, R., \& Jayadinata, A. K. (2016). Pengaruh Model Problem Based Learning Terhadap Kemampuan Berpikir Kreatif Siswa. Jurnal Pena Ilmiah, 1(1), 871-880.

Budiarti, M. I. E., \& Ruslan, M. (2018). Critical Thinking of Extrovert Girls in Problem Solving. In University of Muhammadiyah Malang's 1st International Conference of Mathematics
Education (INCOMED 2017). Atlantis Press.

Budiarti, M. I. E., Ruslan, R., \& Kahar, M. S. (2018). Critical thinking of extrovert boys in problem solving. In International Conference on Mathematics and Science Education of Universitas Pendidikan Indonesia (Vol. 3, pp. 589-592).

Choridah, D. T. (2013). Peran Pembelajaran Berbasis Masalah untuk Meningkatkan Kemampuan Komunikasi dan Berpikir Kreatif Serta Disposisi Matematis Siswa Sma. Infinity Journal. https://doi.org/10.22460/infinity.v $2 \mathrm{i} 2.35$

Fadillah, A. (2016). Pengaruh pembelajaran problem solving terhadap kemampuan berpikir kreatif matematis siswa. Fibonacci: Jurnal Pendidikan Matematika Dan Matematika, 2(1), 1-8.

Hasanah, N., Mardiyana, M., \& Sutrima, S. (2013). Analisis proses berpikir siswa dalam memecahkan masalah matematika ditinjau dari tipe kepribadian extrovert- introvert dan gender. Jurnal Pembelajaran Matematika, 1(4).

Ismayani, A. (2016). Pengaruh penerapan STEM project-based learning terhadap kreativitas matematis siswa SMK. Indonesian Digital Journal of Mathematics and Education, 3(4), 264-272.

Ikromi, S. L. (2018). Meningkatkan Kemampuan Berpikir Kreatif Matematis Siswa SMA Melalui Pembelajaran Open-Ended Pada Materi SPLTV. Jurnal Matematika Statistika Dan Komputasi. 
DOI: https://doi.org/10.24127/ajpm.v9i4.3161

https://doi.org/10.20956/jmsk.v15 i2.5719

Marcia, dkk. (2010). Cross-National Patterns of Gender Differences in Mathematics: A Meta-Analysis. American Psychological Association 2010, 136(1).

Nasution, P. R. (2017). Perbedaan Peningkatan Kemampuan Berpikir Kreatif Matematis dan Kemandirian Belajar Siswa pada Pembelajaran Berbasis Masalah dan Pembelajaran Konvensional di SMPN 4 Padang sidimpuan. Jurnal

Paidagogeo, 2(1), 46-62.

Nursa'adah, F. P., \& Rosa, N. M. (2016). Analisis Kemampuan Berpikir Kreatif Kimia Ditinjau dari Adversity Quotient, Sikap Ilmiah dan Minat Belajar. Formatif: Jurnal Ilmiah Pendidikan MIPA.

Pangestu, N. S., \& Hasti Yunianta, T. N. (2019). Proses Berpikir Kreatif Matematis Siswa Extrovert dan Introvert SMP Kelas VIII Berdasarkan Tahapan Wallas. Mosharafa: Jurnal Pendidikan Matematika. https://doi.org/10.31980/mosharaf a.v8i2.472

Purba, N. E., Surya, E., Syahputra, E., \& Medan, P. U. (2017). Analisis kemampuan berpikir kreatif siswa melalui pemecahan masalah pada materi FPB dan KPK.PPs Unimed Medan, Sumatera Utara. Indonesia
Rasiman, R. (2015). Leveling Of Students'critical Ability In Solving Mathematics Problem Based On Gender Differences. Leveling of Students Critical Thinking Abilities in Mathematics Problem Solving in Line with Gender Differences, 3(4), 307-318.

Taher, T., Erdawati, E., \& Afrizal, A. (2018). Pengaruh Model Problem Based Learning dan Tipe Kepribadian Terhadap Kemampuan Berpikir Kritis Siswa pada Materi Koloid. JRPK: Jurnal Riset Pendidikan Kimia. https://doi.org/10.21009/jrpk.081. 03

Tambunan, N. (2016). Pengaruh Strategi Pembelajaran dan Minat Belajar Terhadap Kemampuan Berpikir Kreatif Matematis Siswa. Formatif: Jurnal Ilmiah Pendidikan MIPA. https://doi.org/10.30998/formatif. v6i3.993 